\title{
Classified Advertising and Meetings
}

\section{CARDIAC ANAESTHESIA}

Clinical research fellowship positions available for one-year appointment commencing July 1994 at the University of Ottawa Heart Institute, Ottawa, Canada. Applicants must be eligible for Canadian certification or hold equivalent $\mathrm{Na}$ tional degree in anaesthesia. Excellent clinical experience in adult acquired and congenital heart disease. Active clinical and basic science research facilities to complement clinical experience. Call $613-761-4940$ or address inquiries

Dr. J.E. Wynands

Ottawa Heart Institute

Room 213, 1053 Carling Avenue

Ottawa, Ontario, Canada KIY 4E9

\section{FAMILY PRACTITIONER WITH} ANAESTHETIC TRAINING

The Almonte General Hospital is seeking the immediate services of a Family Practitioner with Anaesthetic training for the Town of Almonte, Ontario and surrounding Townships. Financial incentives are available. Almonte, with a Hospital catchment population of approximately fifteen thousand $(15,000)$ is located twenty-five miles west of Ottawa with excellent educational, recreational facilities and a fully accredited 52 bed hospital. For details contact:

R.K. Timmons

Chief Executive Officer

Almonte General Hospital

Almonte, Ontario, K0A $1 \mathrm{A0}$

Tel: (613) 256-2500

\section{CLASSIFIED ADVERTISING}

As a service to its readers, the Canadian Journal of Anaesthesia is pleased to accept suitable classified advertisements to announce positions available or wanted, meetings, postgraduate courses, or other events or items of interest to subscribers. Rates for classified advertising (for each insertion): $\$ 40$ for first 5 typeset lines. $\$ 5$ per typeset line (or partial line) thereafter. Minimum charge $\$ 40$. Copy must be received 8 weeks prior to the 1 st of the month of publication. Ad copy, subject to acceptance by the publisher, should be typed double-spaced and mailed or faxed to:

Canadian Journal of Anaesthesia 1 Eglinton Avenue East, Suite 208 Toronto, Ontario, Canada M4P 3A1 Tel. (416) 480-0602, Fax (416) 480-0320 Specially priced display advertising space is also available to non-commercial advertisers.
CLINICAL RESEARCH FELLOW: CHRONIC PAIN MANAGEMENT

A Clinical Research Fellowship position in chronic pain management is available for a oneyear appointment in the Department of Anaesthesia, Ottawa Civic Hospital, Main Division, Ottawa, Canada. Applicants must hold or be eligible for Canadian certification or hold an equivalent national degree in anaesthesia. The Pain Clinic is a multidisciplinary unit and treats both in-patients and out-patients. The clinic offers excellent experience in the diagnosis and treatment of a wide variety of chronic pain syndromes. Foreign medical graduates must meet the educational licensing requirements of the College of Physicians and Surgeons of Ontario. Address inquiries to:

Dr. J.E. Wynands

Ottawa Heart Institute

Room 213, 1053 Carling Avenue

Ottawa, Ontario, Canada KIY 4E9

or call (613) 761-4940

\section{ANAESTHESIA POSITION}

The Conjoint Department of Anaesthesia for the Sudbury General and Laurentian Hospitals has an immediate opening for a full-time anaesthetist. Combined, the hospitals have over 500 acute care beds and provide a full range of surgical services except cardiovascular surgery. The department is al so active in both the Critical Care and Trauma units. Candidates must have attained specialty qualification by the Royal College of Physicians and Surgeons of Canada and be eligible for licensure in the province of Ontario. Interest in intensive care medicine would be an asset. A successful candidate will be joining the current complement of 12 anaesthetists. This allows flexible holiday and professional leave and very reasonable call responsibilities. Sudbury is the largest Northern Ontario community with a population of 100,000 . It offers a wide variety of cultural activities and in particular, is known for its outstanding recreational opportunities. Submit applications to: Dr. Peter Zalan

Chief

Conjoint Department of Anaesthesia

Sudbury General Hospital

700 Paris Street

Sudbury, Ontario P3E 3B5
CERTIFIED ANAESTHETIST - ONTARIO

Welland County General Hospital, a fully accredited acute care facility has an opening for a certified anaesthetist. Welland is located in the central part of the Niagara Peninsula with a catchment area of 60,000 . The hospital's surgical special ties include Obstetrics \& Gynecology, Ophthalmology, Urology, Orthopaedics, General Surgery, Otolaryngology and Oral Surgery. Applicants interested in I.C.U. would be an asset. Interested applicants should make inquiries and/or send a complete C.V, to:

Dr. M. Ngan

Chief

Department of Anaesthesia

Welland County General Hospital

Third Street

Welland, Ontario L3B 4W6

Tel: (416) 732-6111, Ext. 3375

CLINICAL/RESEARCH FELLOWSHIP OBSTETRICAL ANAESTHESIA

A one-year Fellowship in Obstetrical Anaesthesia starting July I, 1994 is available at Women's College Hospital, Toronto, Canada. The hospital is affiliated with University of Toronto and is a referral centre for High Risk Obstetrics. Annual Obstetrical volume is about 3600 deliveries. In addition to clinical and teaching responsibilities, the Fellowship includes protected time for research. Interested candidates must be eligible to sit the Royal College Examinations in Anaesthesia. Please send your $C V$ and three letters of reference to:

Dr. S. Halpern

Director of Obstetrical Anaesthesia

76 Grenville St

Toronto, Ontario M5S 1B2

\section{Meetings - Canada}

Fourth International Cardiac, Thoracic and Vascular Anesthesia Update and Review September 3-6, 1993

Four Seasons Inn on the Park, Toronto, Ontario

For Information:

Anita Guffin

World Association of Cardiac, Thoracic and

Vascular Anesthesia

P.O. Box 287

Port Chester, NY 10573

Telephone: (212) 241-8392 


\section{O.M.A./C.A.S. Annual Meeting}

September 9-11, 1993

Toronto Airport Marriott

For Information:

Dr. Michael Cooke

Mississauga Hospital

100 Queensway West

Mississauga, Ontario L5B IB8

Telephone: (416) 848-7100

Fax: (416) 848-7139

Paediatric Anaesthesia Conference

November 12-14, 1993

Toronto Marriott Hotel (Eaton Centre), Toronto,

Ontario

For Information:

The Hospital For Sick Children

Dept. of Anaesthesia

555 University Avenue

Toronto, ON M5G $1 \times 8$

Telephone: (416) 813-7445

\section{Canadian Anaesthetists' Society}

51st Annual Meeting

June 17-21, 1994

Edmonton, Alberta

For Information:

Ms. Oedile Daniels

Canadian Anaesthetists' Society

1 Eglinton Avenue East, Suite 208

Toronto, Ontario M4P 3A1

Telephone: (416) 480-0602

Fax: (416) 480-0320

\section{Other Meetings}

First International Symposium on the Difficult Airway

September 17-19, 1993

Le Meridien Hotel, Newport Beach, CA

For Information:

MMC/UCI Center for Health Education

2801 Atlantic Avenue

Long Beach, CA 90801

Telephone: (310) 933-3811

Fax: (310) 933-2012
Association of Anaesthetists of

Great Britain and Ireland

and

Canadian Anaesthetists' Society

Annual Scientific Meeting 1993

September 23-24, 1993

Glasgow, Scotland

For Information.

Mrs Lesley Ogg, BOC Educational Coordinator

Association of Anaesthetists of

Great Britain and Ireland

9 Bedford Square, London WC1B 3RA

Tel: 0716311650

Fax: 0716314352

In Canada contact:

Tel: (416) 480-0602

Fax: (416) 480-0320

6th International Congress on Pain,

Anesthesia and Endocrinology

October 5-6, 1993

Drake Hotel, Chicago, Illinois

For Information:

P.J. Morrison

c/o Michael F, Roizen, M.D.

Professor and Chairman

Department of Anesthesia and Critical Care

The University of Chicago

5841 South Maryland Avenue, MC 4028

Chicago, Illinois 60637

Telephone: (312) 702-6699

Fax: (312) 702-1182

6th Annual Update on Pain Management October 8, 1993

Leavey Conference Centre on the Georgetown

University Campus, Washington, D.C.

For Information

Office of Continuing Medical Education

Georgetown University Medical Center

2233 Wisconsin Ave. NW, Suite 333

Washington, D.C. 20007

Telephone: (202) 687-8735

Fax: (202) 687-3019

American Society of Anesthesiologists

1993 Annual Meeting

October 9-13, 1993

Washington, DC

For Information:

Frank Connell

American Society of Anesthesiologists

520 N. Northwest Highway

Park Ridge, Il 60068-2573

Telephone: (708) 825-5586

Fax: (708) 825-1692
International Symposium on Anaesthesia

October 20-22, 1993

Beijing, China

For Information

Mr. Zhang Ming

Secretariat of International Symposium on

Quality Assurance Program in Hospital

P.O. Box 300, CICCST

Beijing 100086, China

Telephone: 8618313335

Fax: 8618316091

Telex: 222337 ICCST CN

47th Postgraduate Assembly in

Anesthesiology

December 11-15, 1993

New York, NY

For Information:

Mr. Kurt G. Becker

Executive Director

New York State Society of Anesthesiologists

41 East 42nd Street, Suite 703

New York, New York 10017

Telephone: (212) 867-7140

Fax: (212) 867-7153

International Symposium on Regional

Anaesthesia and Pain Therapy

April 9-11,1996

Auckland, New Zealand

For Information:

Dr. N. Robertson, ISRA Committee

Department of Anaesthesia

Auckland Hospital

Park Road

Grafton, Auckland

New Zealand 